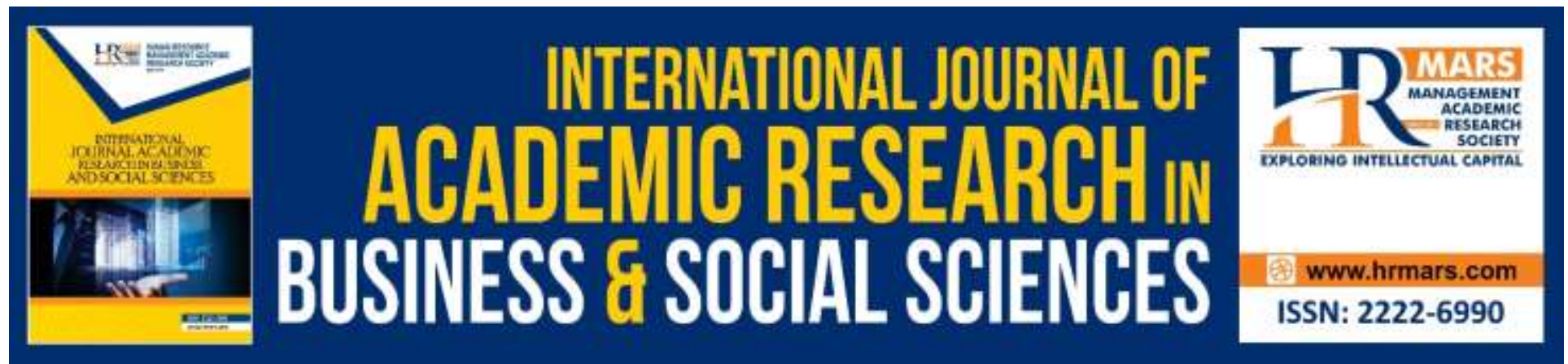

\title{
Factors that affect Willingness to PAY towards Supply of Water Ready to Drink Tirta Montala in Aceh Besar
}

Murtala, Teuku Roli Ilhamsyah Putra, Jariah Abubakar

To Link this Article: http://dx.doi.org/10.6007/IJARBSS/v10-i6/7306

DOI:10.6007/IJARBSS/v10-i6/7306

Received: 09 April 2020, Revised: 12 May 2020, Accepted: 17 June 2020

Published Online: 23 June 2020

In-Text Citation: (Murtala et al., 2020)

To Cite this Article: Murtala, Putra, T. R. I., \& Abubakar, J. (2020). Factors That Affect Willingness to Pay Towards Supply of Water Ready to Drink Tirta Montala in Aceh Besar. International Journal of Academic Research in Business and Social Sciences, 10(6), 353-364.

Copyright: (c) 2020 The Author(s)

Published by Human Resource Management Academic Research Society (www.hrmars.com)

This article is published under the Creative Commons Attribution (CC BY 4.0) license. Anyone may reproduce, distribute, translate and create derivative works of this article (for both commercial and non-commercial purposes), subject to full attribution to the original publication and authors. The full terms of this license may be seen

at: http://creativecommons.org/licences/by/4.0/legalcode

Vol. 10, No. 6, 2020, Pg. 353 - 364

http://hrmars.com/index.php/pages/detail/IJARBSS

JOURNAL HOMEPAGE

Full Terms \& Conditions of access and use can be found at http://hrmars.com/index.php/pages/detail/publication-ethics 


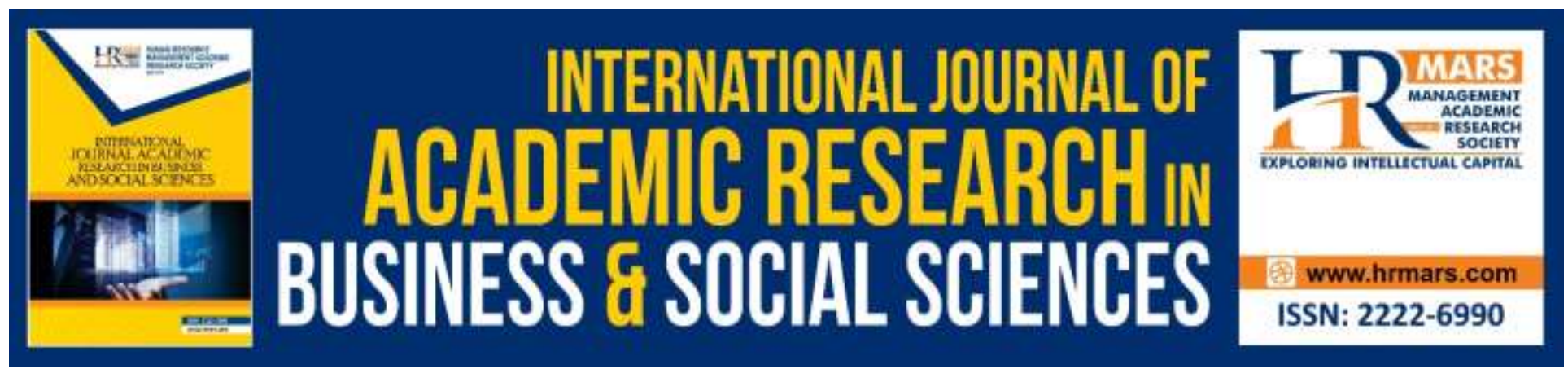

\title{
Factors that affect Willingness to Pay towards Supply of Water Ready to Drink Tirta Montala in Aceh Besar
}

\author{
Murtala ${ }^{1}$, Teuku Roli Ilhamsyah Putra ${ }^{2}$, Jariah Abubakar ${ }^{1}$ \\ ${ }^{1}$ Lecturer of Faculty of Economics and Binsis - Malikussaleh University, Lhokseumawe, ${ }^{2}$ Lecturer \\ of Faculty of Economics and Binsis - Syiah Kuala University, Banda Aceh
}

\begin{abstract}
This study aims to estimate the value of the community's WTP in paying drinking water tariffs for PDAM Tirta Montala in the Sub District of Ingin Jaya District Aceh Besar, and analyzing the effect of income, number of family members and the volume of water needs on the community's ability to pay for PDAM Tirta Montala's drinking water tariffs in Sub District of Ingin Jaya District Aceh Besar. Estimation results show that the average capacity of the community to pay for Tirta Montala Drinking Water in the District of Mau Jaya Aceh Besar is between Rp. 70,000 - 79,999 per month. Per capita income, the number of family members and the volume of water needs, both simultaneously and partially, have a significant effect on the ability of the community to pay for the drinking water tariff of PDAM Tirta Montala in the district of Jaya Jaya Besar. Variations in the ability of the community to pay for drinking water tariffs at Tirta Montala PDAM in the Sub District of Ingin Jaya District Aceh Besar are influenced by variations in per capita income, the number of family members and the volume of water needs by 94.9 percent and the remaining 5.15 percent are influenced by other variables outside the research model this. The Montala Regional Water Company (PDAM) should no longer carry out a policy of increasing PDAM water tariffs for the next few years. The need for additional Water Treatment Plants (WTP) if the PDAM will increase the number of customers until 2030. Need further research for the planning of gradually increasing Water Treatment Plants (WTP) and network planning for PDAM service development.
\end{abstract}

Keywords: Willingness to Pay

\section{Introduction}

In short, clean water is needed to improve the welfare of the community. Therefore, the use of clean water in a country is often considered one of the benchmarks for the ability of its people. Likewise in Indonesia, the use of clean water in Indonesian society in the household sector to the industrial sector will increase the revenue or income of the Regional Water Company (PDAM). 
The increase in the use of clean water, especially households, which are the biggest customers of the Regional Drinking Water Company (PDAM), is closely related to the higher per capita income of the people. That is, the increase in the use of clean water is mainly influenced more by the increasing population and accompanied by an increase in living standards so that it affects the ability to consume basic needs for their living needs. The high use of clean water in the community is actually no element of waste but is a logical demand in improving people's living standards. To find out the development of the population in Aceh Besar Regency can be seen in Table 1.

\section{Table 1}

Number of Households in Aceh Besar Regency in 2009-2019

\begin{tabular}{lll}
\hline Year & Number of Population (Soul) & Number of Households \\
\hline 2009 & 336.61 & 80.152 \\
2010 & 351.418 & 81.453 \\
2011 & 359.464 & 83.23 \\
2012 & 371.412 & 85.996 \\
2013 & 376.491 & 87.793 \\
2014 & 384.618 & 89.054 \\
2015 & 391.642 & 91.014 \\
2016 & 402.411 & 93.411 \\
2017 & 410.124 & 96.114 \\
2019 & 413.114 & 98.112 \\
\hline
\end{tabular}

Source: BPS Aceh 2019

Table 1 shows the number of households in Aceh Besar District has been increasing every year along with the increasing population in the Regency, in 2009 the number of households was 80,152 households, increasing in 2009 to 81,453 . Furthermore in 2010 it continued to grow to 81,453 households and increased again in 2019 to 98,112 households. This has consequences for increasing demand for drinking water in Aceh Besar District.

The population in Aceh Besar District is increasing every year and of course it has an impact on the demand for drinking water. However, not all sub-districts in Aceh Besar District have PDAM water pipe connections, so there are several sub-districts that have not been served with clean water, especially drinking water. Of the 23 sub-districts in Aceh Besar District, only 7 districts are connected by PDAM pipes. These districts can be presented in Table 2. 
INTERNATIONAL JOURNAL OF ACADEMIC RESEARCH IN BUSINESS AND SOCIAL SCIENCES

Vol. 10, No. 6, June, 2020, E-ISSN: 2222-6990 @ 2020 HRMARS

\section{Table 2}

Subdistricts in Aceh Besar District which are flowed by PDAM water

\begin{tabular}{lll}
\hline Number & Sub-District & Number of Customers \\
\hline 1 & Jantho & 1.593 \\
2 & Seulimuem & 926 \\
3 & Siron & 11.002 \\
4 & Darul Imarah & 9.860 \\
5 & Montasik & 4 \\
6 & Samahani & 66 \\
7 & Indrapuri & 350 \\
\hline
\end{tabular}

Source: BPS Aceh 2019

From Table 2 it can be seen that the sub-districts in Aceh Besar that have a lot of PDAM water customers are in Siron Subdistrict with 11,002 customers, followed by Darul Imarah Subdistrict with 9,860 customers, and the lowest number of customers is in Montasik Subdistrict. Another process is the ability of Tirta Montala to produce water that is still relatively limited. This condition has an impact on decreasing clean water and drinking water to the people in the Aceh Besar Region

At present there are seven sub-districts that have PDAM water flowing in Aceh Besar District, but there are still constraints such as the supply of clean water that has not been balanced with the needs of the community in Aceh Besar District, the need is greater than the capacity of water produced by Aceh Besar PDAM, in fact there are several regions PDAM pipes that have been installed, but the smoothness of clean water is still often hampered / jammed. For more details about the distribution of water that is channeled to the community / customers who are connected by PDAM pipes can be seen in Table 3.

Table 3

Tirta Montala PDAM Water Distribution Distribution Year 2008 - 2019

\begin{tabular}{llll}
\hline Year & Water distribution (M3) & Population (Soul) & $\begin{array}{l}\text { Average Water Needs / Day } \\
\text { / Capita }\end{array}$ \\
\hline 2008 & 2.432 .577 & 327.012 & 20,38 \\
2009 & 3.563 .877 & 336.61 & 29,01 \\
2010 & 4.099 .811 & 351.418 & 31,96 \\
2011 & 4.689 .908 & 359.464 & 35,75 \\
2012 & 4.638 .355 & 371.412 & 34,21 \\
2013 & 5.292 .316 & 376.491 & 38,51 \\
2014 & 5.825 .208 & 384.618 & 41,49 \\
2015 & 6.323 .266 & 392.584 & 44,13 \\
2016 & 6.847 .361 & 401.116 & 48,14 \\
2017 & 7.223 .144 & 408.314 & 52,23 \\
2019 & 7.823 .354 & 415.641 & 55,64 \\
\hline
\end{tabular}

Source: BPS Aceh and PDAM Tirta Montala, 2019 
In Table 3 it can be seen that the amount of water distribution by PDAM PT. Tirta Montala is increasing every year, but the quality of water from PDAMs in several sub-districts in Aceh Besar that has no water can still not enjoy the quality of the water supplied by PT. Tirta Montala, the water received by customers is still not able to be directly consumed, even sometimes must be filtered first due to the turbidity of water coming out of the pipe, while the population continues to increase each year.

Efforts to increase the amount of clean water consumption in an area both as a whole and in the household sector need to be considered by identifying factors that affect the ability of the community to pay water tariffs, among others: water price factors, population, number of household heads, regional income, income and development region, education and service. Of the several factors obtained, it can be planned both strategies or other plans that are tailored to several factors that can support the increase in water consumption of PDAMs. Until 2016 the number of PDAM customers in the city of Banda Aceh reached 53,567 both active and inactive. The number of active customers reached 42,998 and 10,569 inactive customers (Source: PDAM Tirta Montala, 2017).

This gives an illustration that the services provided by PDAM Tirta Montala are still low so that many customers are no longer active in using PDAM Tirta Montala services. Other research conducted by (Islam at al, 2014) in Bangladesh states that PAPs are strongly influenced by safe water supplies, risk zones for community dwellings, household incomes, volume of water consumption, awareness of pollution from springs. In another study (Maddison, 2005) and (Whittington, 2010) said that WTP is largely determined by investment costs and water supply operations, meaning that the higher the investment costs, the lower the WTP and conversely the lower investment and operational costs will increasingly WTP. The purpose of this study is to estimate the value of community PAPs to improve services and improve water flow in the Tirta Montala Aceh Besar PDAM. Analyzing the effect of income, number of family members and the volume of water needs on the ability of the community to pay the water tariffs for PDAM Tirta Montala Aceh Besar.

\section{Research Methods}

\section{Scope and Research Location}

This research was conducted at the Tirta Montala PDAM in the District of Mau Jaya, Aceh Besar District, Aceh Province, towards the community / households that use water sources from the Tirta Montala PDAM. The research variable is limited only to the ability to pay drinking water tariffs as the dependent variable and per capita income per month, the level of education, and the volume of water requirements as independent variables.

\section{Data Source}

The type of data used in this study are primary and secondary data. Primary data is data obtained directly from the field, interviews directly with respondents and through a list of questions (questionnaire) given to small business owners. Secondary data is data sourced from publications in various government agencies, including the Central Statistics Agency (BPS) of Aceh Province. and other related institutions related to this research. 


\section{Method of Collecting Data}

\section{Data collection is done by using}

1. Primary data is data obtained through interviews with prepared questionnaires and direct observations in the field.

2. Secondary data is data collection through documentary techniques and literature study. Documents used to obtain data obtained from PDAM Tirta Montala, BPS, PU and the Regional Financial Management Agency (BPKD).

\section{Population and Sample}

The population is the whole material or element being investigated (Marzuki, 2001: 51). The population in this study were all water customers of Tirta Montala PDAM, Aceh Besar Regency. By examining part of the population, it is hoped that the results obtained will be able to describe the nature of the population concerned. The sample is a portion of the number and characteristics possessed by the population (Sugiyono, 2002). The population in this study is the number of PDAM water customers in the Six Villages in the Ingin Jaya District, Aceh Besar Regency. For more details can be seen in Table 4.

\section{Table 4}

\section{Population and Sample}

\begin{tabular}{|l|l|l|l|}
\hline Number & Village & Population & Sample \\
\hline 1 & Kayee Lee & 125 & 41 \\
\hline 2 & Lam Teungoh & 110 & 36 \\
\hline 3 & Lubok Sukon & 123 & 40 \\
\hline 4 & Lam Ue & 95 & 31 \\
\hline 5 & Lamdaya & 81 & 27 \\
\hline 6 & Lambada & 76 & 25 \\
\hline & Jumlah & $\mathbf{6 1 0}$ & $\mathbf{2 0 0}$ \\
\hline
\end{tabular}

Source: Ingin Jaya District Head Office 2019

Sampling was done using the method of "simple random sampling" of 32.78 percent of the total population in each study village, so that a sample of 200 respondents was obtained. To find out the magnitude of the community's WTP value on service improvement and water flow improvement with PDAM Tirta Montala Aceh Besar, the WTP value obtained from each respondent is in the form of the maximum rupiah value that respondents are willing to pay for water services, processed to get an average value (mean) of the WTP value using the formula (Aadland, D., Caplan, 2004):

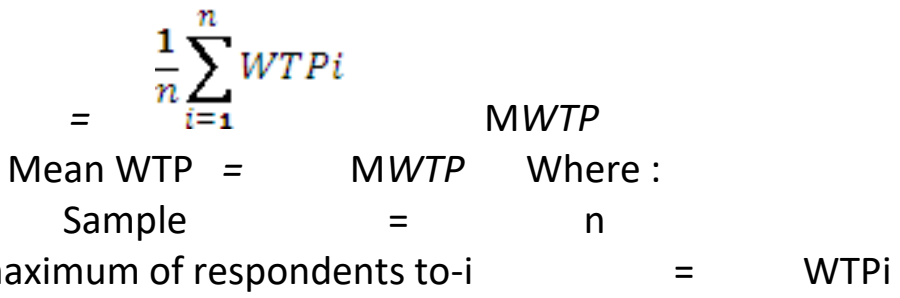

Value WTP maximum of respondents to- $i=$ WTPi

The analytical tool used to analyze the willingness of the community to pay water tariffs is the Contingency Valuation Method (CVM) using a measure of welfare Willingness to 
Pay (WTP), community perceptions of the level of service obtained and the quality of cleanliness in the environment. The use of CVM is intended to determine the water tariff in accordance with the wishes of the people of the city of Banda Aceh.

To find out the effect of income, the number of family members and the volume of water needs on the community's ability to pay for drinking water tariffs of the Tirta Montala Aceh Besar PDAM, a model was developed by Islam Nasreen Khan, Roy Brouwer (2014) with the following equation.

Where :

$$
W T P=\alpha+\beta_{1} Y+\beta_{2} E+\beta_{3} V+e
$$

WTP = Community's ability to pay water tariffs

$\mathrm{Y} \quad=$ Monthly income per capita (Rp/kk/mounth)

$\mathrm{E} \quad=$ Number of family members

$\mathrm{V}=$ Volume of water demand $\left(\mathrm{m}^{3} / \mathrm{bln}\right)$

$\alpha \quad=$ Intersep

$\beta_{1}-\beta_{3}=$ Regression coefficient

$\mathrm{e} \quad=$ error term

From the above equation, in addition to getting the regression coefficient, it also directly gets the elasticity function and will be estimated by using the Ordinary Least Square (OLS) method and pay attention to the possibility of deviations from the classical assumptions, namely multicollinearity, heteroscedasticity and autocorrelation.

\section{Results and Discussion}

\section{Willingness or Desire of Respondents to Pay for PDAM Tirta Montala's Water (WTP)}

To find out how the ability or desire of the people of Aceh Besar in paying for Drinking Water at PDAM Tirta Montala in the Ingin Jaya District, Aceh Besar Regency can be seen in Table 5 .

Table 5 WTP Community Group, Ingin Jaya District, Aceh Besar Regency

\begin{tabular}{llll}
\hline Number & WTP group & Frequency & Percentage \\
\hline 1 & $<$ Rp.50.000 & 21 & 10,5 \\
2 & Rp.50.000-59.999 & 22 & 11,0 \\
3 & Rp.60.000-69.999 & 38 & 19,0 \\
4 & Rp.70.000-79.999 & 51 & 25,5 \\
5 & Rp.80.000-89.999 & 30 & 15,0 \\
6 & Rp.90.000-99.999 & 24 & 12,0 \\
7 & $>$ Rp.100.000 & 14 & 7,0 \\
\hline
\end{tabular}

Source: Data Processing Results, 2019

Table 5 shows the willingness or desire of the people of Aceh Besar to pay for Drinking Water at Tirta Montala PDAM in District of Wish Jaya, Aceh Besar District. The PAPs who have the ability to pay below Rp.50,000 are 10.5 percent. People who have the ability to pay between 
Rp.50,000-59,999 are 11 percent. People who have the ability to pay between Rp. 60,000-69,999 are 19 percent. People who have the ability to pay between Rp. 70,000-79,999 are 25 percent. People who have the ability to pay between Rp. 80,000-89,999 are 15 percent. People who have the ability to pay between Rp. 90,000-99,999 are 11 percent. People who have the ability to pay above Rp. 100,000 are 7 percent. The average capacity to pay for Tirta Montala drinking water by the large Acehnese community is between Rp. 70,000 - 79,999 per month.

\section{Analysis of Household Per capita Income in District of Ingin Jaya, Aceh Besar Regency}

How is the description of the income per capita of the people in the District of Jaya Jaya, Greater Aceh District can be seen in Table 6.

\section{Table 6}

Per Capita Community Income of Ingin Jaya District, Aceh Besar District

\begin{tabular}{llll}
\hline Number & Income per capita (Rp) & Frequency & Percentage \\
\hline 1 & $<2.000 .000$ & 19 & 9,5 \\
2 & $2.000 .000-2.999 .999$ & 16 & 8,0 \\
3 & $3.000 .000-3.999 .999$ & 32 & 16,0 \\
4 & $4.000 .000-4.999 .999$ & 54 & 27,0 \\
5 & $5.000 .000-5.999 .999$ & 36 & 18,0 \\
6 & $6.000 .000-6.999 .999$ & 26 & 13,0 \\
7 & $>7.000 .000$ & 17 & 8,5 \\
\hline & Total & 200 & 100,0 \\
\hline
\end{tabular}

Source: Data Processing Results, 2019

Table 6 shows the average income of the people of Ingin Jaya District, Aceh Besar District. Community groups with an income of less than Rp. 2,000,000 are 9.5 percent. The community group that has an income of between Rp. 2,000,000-2,999,999 is 8.5 percent. Community groups that have an income of between Rp. 3,000,000-3,999,999 are 16.0 percent. The community group that has an income of between Rp.4,000,000-4,999,999 is 27 percent. Community groups that have an income of between Rp.5,000,000-5,999,999 are 18 percent. Community groups that have an income of between Rp.6,000,000-6,999,999 are 13 percent. Community groups that have an income of more than Rp.7,000,000 are 8.5 percent. The average monthly income of the Wish Jaya District of Aceh Besar District is between Rp.4,000,000$4,999,999$.

\section{Analysis of the Number of Family Members of Household in District Ingin Jaya District, Aceh Besar District}

An illustration of the number of community family members in the Ingin Jaya Sub-District of Aceh Besar Regency can be seen in Table 7. 
INTERNATIONAL JOURNAL OF ACADEMIC RESEARCH IN BUSINESS AND SOCIAL SCIENCES

Vol. 10, No. 6, June, 2020, E-ISSN: 2222-6990 @ 2020 HRMARS

\section{Table 7}

Number of Family Members of District Ingin Jaya District, Aceh Besar District

\begin{tabular}{llll}
\hline Number & Number of Family Members & Frequency & Percentage \\
\hline 1 & $1-2$ & 52 & 26,0 \\
2 & $3-4$ & 108 & 54,0 \\
3 & $5-6$ & 34 & 17,0 \\
4 & $>7$ & 6 & 3,0 \\
\hline & Total & 200 & 100,0 \\
\hline
\end{tabular}

Source: Data Processing Results, 2019

From Table 7 shows the average number of family members in the district of Suka Jaya, Aceh Besar District. Respondents who have a family member of between 1-2 people are 26 percent. Respondents who have a family member of between 3-4 people as much as 54 percent. Respondents who have a number of family members between 5-6 people as much as 17 percent. Respondents who have a greater number of family members are 7 people by 3 percent.

\section{Analysis of Average Volume of Water Needs by Ingin Jaya Subdistrict, Aceh Besar District}

The description of drinking water consumption in PDAM Tirta Montala by the community in the District of Mau Jaya, Aceh Besar Regency can be seen in Table 8.

\section{Table 8}

Volume of Water Needs of District People from Jaya Aceh Besar Regency ( $\left.\mathrm{M}^{3}\right)$

\begin{tabular}{llll}
\hline Number & Volume of Water Needs & Frequency & Percentage \\
\hline $\mathbf{1}$ & $0-10$ & 9 & 4,5 \\
2 & $11-20$ & 34 & 17,0 \\
3 & $21-30$ & 22 & 11,0 \\
4 & $31-40$ & 24 & 12,0 \\
5 & $41-50$ & 25 & 12,5 \\
6 & $51-60$ & 36 & 18,0 \\
7 & $61-70$ & 26 & 13,0 \\
8 & $71-80$ & 7 & 3,5 \\
9 & $81-90$ & 8 & 4,0 \\
10 & $91-100$ & 9 & 4,5 \\
\hline & Total & 200 & 100,0 \\
\hline
\end{tabular}

Source: Data Processing Results, 2019

Table 8 shows the average volume of water demand used by the people of the Ingin Jaya District, Aceh Besar District. Is between 51-60 m3 with a percentage of 18 percent. To find out the effect of income, number of family members and the volume of water needs on the ability of the community to pay for the drinking water tariff of PDAM Tirta Montala in the Sub District of Ingin Jaya District Aceh Besar, the final results are presented in Table 9. 
INTERNATIONAL JOURNAL OF ACADEMIC RESEARCH IN BUSINESS AND SOCIAL SCIENCES

Vol. 10, No. 6, June, 2020, E-ISSN: 2222-6990 @ 2020 HRMARS

Table

Regression Calculation Results

\begin{tabular}{|l|l|l|l|l|l|}
\hline Model & B & t & Sig. & F & Sig F \\
\hline (Constant) & $-0,044$ & 0,579 & $-0,556$ & 1425,299 & 0,00 \\
Income per capita & 0,543 & 0,000 & 9,949 & & \\
Number of family & 0,257 & 0,002 & 3,186 & Adjusted R & \\
members & 0,955 \\
Volume of water demand & 0,243 & 0,000 & 6,121 & & \\
\hline
\end{tabular}

Source: Data Processing Results, 2019

From the results of the study, the final equation estimate is $Y=-0.044+0.543 Y+0.257 \mathrm{E}$ $+0.243 \mathrm{~V}$. From this equation, a constant of -0.044 is obtained, which means that if per capita income, the number of family members and the volume of water needs are considered constant, the ability of the community to pay for the drinking water tariff of PDAM Tirta Montala in the Ingin Jaya Aceh Besar District decreases by 0.044 percent.

Per capita income obtained a regression coefficient of 0.543 , meaning that every change of 1 million rupiahs to per capita income will affect the ability of the community to pay for drinking water tariffs at Tirta Montala PDAM in the district of Jaya Jaya Besar by 0.543 percent, assuming a variable number of family members and the volume of water demand is considered constant. This is consistent with research conducted by Polyzou, E. N. Jones dan K.I. Evangelinos (2011), Awad (2012), Jessoe (2013) and Groothuisa, at all (2015), income has a significant effect on people's ability to pay for clean water. In contrast to research conducted by Li Li a, Chong Su Li a (2016) which states, the willingness of rural communities in Vietnam to pay for water to be preserved in bottles. There are many households in poor conditions, so that part of the community relies on rainwater as the main source of drinking water. This condition affects the unwillingness of people to buy water preserved in bottles, even though prices are lowered.

The estimated coefficient of the number of family members is 0.257 meaning that every 1 person increase in the number of family members will affect the ability of the community to pay the drinking water tariff of PDAM Tirta Montala in the Sub District of Ingin Jaya District Aceh Besar by 0.257 percent assuming the variable income per capita and the volume of water needs are considered constant. This is also consistent with other studies conducted by Fitria, et al (2012), Apriliyana (2015), Nasution, et al (2015), which affect the value of the Aek Arnga Spring Willingness to Pay (WTP) is the average number of members family.

The estimated coefficient of water demand volume of 0.243 means that every $1 \mathrm{~m} 3$ increase in the volume of water demand will have an effect on increasing the ability of the community to pay for the drinking water tariff of PDAM Tirta Montala in the Sub District of Ingin Jaya District Aceh Besar by 0.243 percent assuming variable income per capita and the number of family members considered constant. This is also in accordance with the theory said by Islam Nasreen Khan, Roy Brouwer (2014) and Burt et al (2017), WTP is strongly influenced by the volume of water consumption.

The determinant coefficient value (Adjusted $\mathrm{R}$ Square of 0.955 ) means that variations in the ability of the community to pay for drinking water tariffs of PDAM Tirta Montala in the Sub District 
of Ingin Jaya District Aceh Besar are influenced by variations in income per capita, the number of family members and the volume of water needs by 95.5 percent and the rest by 4.5 percent is influenced by other variables outside this research model.

Proving the hypothesis simultaneously obtained the calculated $F$ value of 1,425 is greater than the $\mathrm{F}$ table 4.2051 at a $95 \%$ convident interval level means that simultaneous income per capita, the number of family members and the volume of water needs have a significant effect on the ability of the community to pay for the PDAM Tirta Montala drinking water tariff in Sub District of Ingin Jaya District Aceh Besar.

Proving the hypothesis partially, the value of $t$ arithmetic for variable income per capita of 9,949 is greater than $t$ table 1,241 at a 95\% interval rate means that partially per capita income has a significant effect on the ability of the community to pay for drinking water tariffs in PDAM Tirta Montala in Ingin Jaya District Aceh Besar.

Proving the hypothesis partially obtained the value of $t$ arithmetic for the variable number of family members amounted to 3.186 greater than t table 1.241 at $95 \%$ convident interval level means that partially the number of family members has a significant effect on the ability of the community to pay for drinking water tariffs at Tirta Montala PDAM in the District of Jaya Aceh Besar.

Proving the hypothesis partially obtained the value of $t$ arithmetic for the variable volume of water needs of 6.121 is greater than t table 1.241 at a $95 \%$ interval level means that partially the volume of water needs significantly influences the ability of the community to pay for drinking water tariffs at Tirta Montala PDAM in Kecamatan Jaya Aceh Besar.

\section{Conclusion}

a. The average capacity of the community to pay for Tirta Montala Drinking Water in the Ingin Jaya Aceh Besar sub-district is between Rp. 70,000-79,999 per month.

b. Per capita income, the number of family members and the volume of water needs, both simultaneously and partially, have a significant effect on the ability of the community to pay for the drinking water tariff of PDAM Tirta Montala in the district of Jaya Jaya Besar.

c. Variations in people's ability to pay for drinking water tariffs at Tirta Montala PDAM in the Ingin Jaya Aceh Besar District are influenced by variations in per capita income, the number of family members and the volume of water needs by 95.5 percent and the remaining 4.5 percent are influenced by other variables outside the research model this.

\section{Suggestion}

a. The Montala Regional Water Company (PDAM) should no longer carry out a policy of increasing PDAM water tariffs for the next few years.

b. The need for additional Water Treatment Plants (WTP) if the PDAM will increase the number of customers until 2030.

c. Further research is needed to plan for the gradual addition of IPA and PDAM service development network planning.

\section{References}

Aadland, D., Caplan, A. (2004). Incetive Incompatibility And Starting Point Bias In Iterative Valuation Questions: Comment. Land Econ, 80(2), 312-315. 
Apriliyana, P. (2015). Analisis Pembiyaan Air Minum Masyarakat yang Memanfaatkan Sumber Mata Air Dalam Pemenuhan Kebutuhan Air Domestik di Desa Wangunsari, Kecamatan Lembang, Kabupaten Bandung Barat. Jurnal Ekonomi Pembangunan, 3(2), 54-69.

Zachary, B., Robert, M. N., Mbatia, Y., Msimbe, V., Brown, J., Thomas, F. C., Hamisi, M. M., I. R. (2017). User Preferences And Willingness To Pay For Safe Drinking Water: Experimental Evidence From Rural Tanzania. Social Science \& Medicine, 63-71.

Khan, I. N., Brouwer, R. H. Y. (2014). Household's Willingness To Pay For Arsenic Safe Driking Water In Bangladesh. Journal of Environmental Managemant, 151-161.

Jayanti, Z. (2013). Analisis Penentuan Air Besih Dan Keterjangkauan Daya Beli Masyarakat Terhadap Air Bersih Kota Jakarta 9Studi Kasus pada PT.XYZ). Jurnal Kajian Manajemen Bisnis, 1(1), 46-54.

Li Li, A., Chong, Su Li A. D. W. (2016). Assessing Household Willingness To Pay For Bottled Water In Rural Areas Of The Mekong Delta, Vietnam. Water Resources And Rural Development, 3649.

Mankiw, N. G. (2004). Principle Of Economics (Edisi Tiga). Jakarta: Salemba Empat.

Martin. (2004). Sistem Distribusi Air Minum. Jakarta: Ekamitra Engeenering.

Miller, M. (2000). Teori Ekonomi Entermediate (Edisi Tiga; Raja, ed.). Jakarta: Grafindo Persada.

Nicholson, W. (2005). Mikroekonomi Intermediate dan Aplikasinya (Edisi 8; M. dan A. Aziz, ed.). Jakarta: Erlangga.

Polyzou, E. N., Jones, dan K. I., Evangelinos, C. P. H. (2011). Willingness To Pay For Drinking Water Quality Improvement And The Influence Of Social Capital. The Journal Of Socio-Economic, 78-40.

Whittington, D. (2010). What Have We Learned From 20 Years Of Stated Preferencen In LessDeveloped Countries? Annu. Rev. Resour. Econ, 2(4), 209-236. 